\title{
BIMWIN SEBAGAI STRATEGI KOMUNIKASI BIMAS ISLAM KABUPATEN PONOROGO DALAM MENCEGAH PERCERAIAN
}

\author{
Mohammad Luthfi, mohammadluthfi@unida.gontor.ac.id \\ M. Rifa'i, mrifai@unida.gontor.ac.id \\ Universitas Darussalam Gontor \\ Jalan Raya Siman Km. 06 Ponorogo
}

\begin{abstract}
This study aims to find out BIMWIN as a communication strategy for the Islamic Community Guidance in Ponorogo Regency in preventing divorce. The location of this study was located in the Islamic Guidance Office of Ponorogo Regency with the research subjects being the Head of the Islamic Guidance Section in Ponorogo Regency, the chief executive of BIMWIN, the facilitator and BIMWIN participants. The method used in this research is a qualitative descriptive approach with data collection methods through interviews, observation and documentation. The results showed that in an effort to prevent divorce, the Islamic Community Guidance in Ponorogo Regency carried out Marriage Guidance activities for prospective bridal partners. The mapping of communicants is based on the sociological and psychological aspects of the participants. The message delivery strategy is packaged in the form of lectures and group discussions that focus on participants. The media used are LCD projectors, white boards and the Sakinah Family Foundation book. The strategy of selecting communicators is based on aspects of credibility and attractiveness so that those who are used as communicators in the implementation of BIMWIN are facilitators who have been certified in the field of motivators and sakinah family counselors.
\end{abstract}

Keywords: BIMWIN, Communication Strategy, Divorce.

\section{ABSTRAK}

Penelitian ini bertujuan untuk mengetahui BIMWIN sebagai strategi komunikasi Bimas Islam Kabupaten Ponorogo dalam mencegah perceraian. Lokasi penelitian ini bertempat di kantor Bimas Islam Kabupaten Ponorogo dengan subyek penelitian Kepala Seksi Bimas Islam Kabupaten Ponorogo, ketua pelaksana BIMWIN, fasilitator dan peserta BIMWIN. Metode yang digunakan dalam penelitain ini adalah pendekatan deskriptif kualitatif dengan metode pengumpulan data melalui wawancara, observasi dan dokumentasi. Hasil penelitian menunjukkan bahwa dalam upaya mencegah perceraian, Bimas Islam Kabupaten Ponorogo melaksanakan kegiatan Bimbingan Perkawinan bagi calon pasangan pengantin. Pemetaan komunikan didasarkan pada aspek sosiologis dan psikologis peserta.strategi penyampaian pesan dikemas dalam bentuk ceramah dan diskusi kelompok yang berfokus pada peserta. Media yang digunakan adalah LCD proyektor, papan tulis dan buku Fondasi Keluarga Sakinah. Strategi pemilihan komunikator berdasarkan aspek kredibilitas dan daya tarik sehingga yang dijadikan sebagai komunikator dalam pelaksanaan BIMWIN adalah fasilitator yang telah sertifikasi dalam bidang motivator dan konselor keluarga sakinah.

Kata kunci: BIMWIN, Strategi Komunikasi, Perceraian.

\section{PENDAHULUAN}

Fenomena perceraian di Kabupaten Ponorogo masih cukup tinggi. Pada tahun 2017, Pengadilan Agama Ponorogo telah memutus 1.940 kasus perceraian. Penyebab munculnya perceraian sebagian besar didominasi oleh faktor ekonomi, adanya salah satu pihak meninggalkan keluarga serta 
faktor perselisihan dan pertengkaran suami istri yang menyebabkan hubungan rumah tangga menjadi tidak harmonis sehingga berujung pada perceraian. Fenomena ini menunjukkan bahwa telah terjadi kegagalan pasangan suami istri dalam membangun hubungan rumah tangga yang harmonis untuk mencapai tujuan perkawinan yang mulia. (Sumber: Pengadilan Agama Ponorogo)

Sejatinya tujuan perkawinan antara suami dan istri bukan hanya berorientasi pada hal-hal yang bersifat biologis, tetapi memiliki tujuan yang lebih luas meliputi segala aspek kehidupan rumah tangga baik lahiriyah maupun batiniah. Perkawinan merupakan perjanjian yang kokoh (mitsaqan ghalizhan), perintah pergaulan yang layak antara suami dan istri untuk mencapai ketaqwaan dan keimanan kepada Allah SWT dengan perilaku baik dan mulia dalam keluarga sebagaimana telah disyari'atkan dalam ajaran Islam.

Hukum Islam telah merumuskan bahwa tujuan perkawinan antara laki-laki dan perempuan adalah untuk mewujudkan kehidupan rumah tangga yang sakinah mawaddah warahmah. Yaitu rumah tangga yang tenteram, penuh kasih sayang, serta bahagia lahir dan batin. Sesuai firman Allah SWT dalam QS. Ar-Ruum ayat 21 yang artinya:

"Dan diantara tanda-tanda kekuasaanNya ialah (dia) yang menciptakan untukmu istri dari jenismu sendiri, supaya kamu cenderung dan merasa tenteram kepadanya dan dijadikan-Nya diantaramu rasa dan kasih sayang. Sesungguhnya pada yang demikian itu benar-benar terdapat tanda-tanda bagi kaum yang berfikir".

Untuk mewujudkan keluarga sakinah sesuai ajaran Islam, maka pasangan suami istri harus memiliki bekal pemahaman yang cukup terkait bagaimana cara membangun keluarga yang baik dan mulia, meliputi perencanaan yang matang, tujuan yang jelas, landasan dan bekal yang cukup agar perkawinan dapat dibangun dengan kokoh sehingga mampu melahirkan keluarga yang sakinah.

Dalam upaya meningkatkan kualitas perkawinan yang baik dan mulia sesuai ajaran Islam, Bimbingan Masyarakat (BIMAS) Islam Kabupaten Ponorogo menyelenggarakan kegiatan Bimbingan Perkawinan (BIMWIN) bagi pasangan calon pengantin (pra-nikah) dalam rangka mewujudkan rumah tangga yang sakinah mawaddah wa rahmah. Kegiatan ini selaras dengan tugas dan fungsi Bimas Islam dalam memberikan bimbingan bagi masyarakat khususnya pasangan suami istri dalam upaya meningkatkan kualitas kehidupan keluarga yang harmonis.

Kesuksesan program BIMWIN yang diselenggarakan Bimas Islam Kabupaten Ponorogo sangat ditentukan oleh bagaimana strategi komunikasi diterapkan dalam pelaksanaannya. Komunikasi memiliki peran penting dalam aktivitas bimbingan yang dilakukan Bimas Islam kepada masyarakat khususnya calon pasangan pengantin sebagai peserta BIMWIN dalam rangka menyukseskan keberhasilan program pemerintah untuk mewujudkan keluarga sakinah sehingga tingginya perceraian dapat diminimalisir.

R. Wayne Pace dalam Effendy mengatakan bahwa tujuan sentral dari strategi komunikasi adalah untuk membangun suatu pengertian agar terdapat kesamaan makna antara pihak penerima pesan (komunikan) yang dalam hal ini adalah calon pasangan pengantin selaku peserta BIMWIN untuk 
bisa memahami dan mengerti terhadap pesan yang disampaikan oleh Bimas Islam selaku pengirim pesan (komunikator) serta bagaimana strategi penerimaan pesan tersebut terus dibina dan dipelihara dengan baik dengan cara memotivasi komunikan agar melakukan kegiatan atau berperilaku sebagaimana diha-rapkan oleh komunikator. (Effendy, 2013: 32).

Untuk itu penerapan strategi komunikasi dibutuhkan dalam upaya mencapai keberhasilan program BIMWIN secara efektif. Melalui strategi komunikasi yang baik dan terencana, pelaksanaan BIMWIN tentu memberikan solusi konkrit dalam upaya meningkatkan kualitas kehidupan masyarakat yang lebih baik khususnya bagi pasangan suami istri dalam membangun rumah tangga yang sakinah dan setiap permasalahan yang muncul dalam keluarga dapat di selesaikan dengan baik dan tidak berujung pada terjadinya perceraian. Seorang pakar perencana komunikasi, Middleton mengatakan bahwa strategi komunikasi merupakan sebuah kombinasi yang terbaik dari elemen-elemen komunikasi, mulai dari pengirim (komunikator), pesan, saluran (media), penerima (komunikan) sampai pada pengaruh (efek) yang dirancang untuk mencapai tujuan komunikasi yang optimal. (Cangara. 2013: 61)

Dalam konteks BIMWIN, Bimas Islam Kabupaten Ponorogo langkah pertama yang harus dilakukan adalah pemetaan komunikan terlebih dahulu sebelum kegiatan dilaksanakan. Komunikan merupakan salah satu aktor penting yang tidak boleh diabaikan dalam proses komunikasi karena keberhasilan kegiatan komunikasi tidak lepas dari adanya penerimaan dari komunikan, sehingga salah satu tugas dari komunikator adalah melakukan pemetaan terhadap komunikan sebelum proses komunikasi berlangsung. Cangara (2016) mengatakan bahwa terdapat tiga aspek yang harus diperhatikan oleh komuni-kator menyangkut komunikan, yaitu aspek sosiodemografik, aspek psikologis dan aspek karakteristik perilaku komunikan. (Cangara, 2016: 171).

Kemudian aspek pesan yang akan disampaikan juga harus sesuai dengan situasi dan kondisi yang dialami oleh komunikan, pesan harus sesuai dengan kebutuhan dan harapan komunikan. Langkah selanjutnya adalah pemilihan media komunikasi sebagai saluran dalam menyampaikan pesan komunikasi. Media menentukan terhadap keberhasilan program BIMWIN yang diselenggarakan oleh Bimas Islam Kabupaten Ponorogo. Media yang digunakan menjadi salah satu faktor penting dalam membentuk dan memengaruhi pesan yang disampaikan. Pesan yang disampaikan melalui media berbeda tentu akan memiliki pengaruh yang berbeda pula terhadap komunikasi yang dilakukan. Setelah itu, aspek narasumber selaku komunikator dalam menyampaikan materi BIMWIN, menyangkut krediblitas dan kompetensi yang dimiliki dalam berkomunikasi juga menjadi kunci penentu keberhasilan kegiatan komunikasi yang dijalankan terutama dalam hal komunikasi yang bersifat persuasif.

Untuk itu, penulis tertarik untuk mengetahui lebih jauh bagaimana strategi komunikasi Bimas Islam Kabupaten Ponorogo dalam penerapan program BIMWIN dalam rangka mewujudkan keluarga sakinah sehingga munculnya perceraian di Kabupaten Ponorogo dapat cegah. 


\section{METODE PENELITIAN}

Penelitian ini menggunakan pendekatan deskriptif kualitatif. Pendekatan ini dimaksudkan untuk memahami fenomena tentang apa yang dialami oleh informan seperti persepsi, sikap, perilaku dan motivasi secara holistik. Sebagaimana dikatakan Kriyantono (2014) bahwa tujuan utama dari pendekatan deskriptif adalah untuk mendeskripsikan, menggambarkan secara sistematis, faktual dan akurat mengenai fakta-fakta, sifat-sifat serta hubungan antar fenomena yang diselidiki.

Pengumpulan data dalam penelitian ini dilakukan melalui wawancara mendalam (in dept-interview) dengan Kepala Seksi Bimas Islam, Ketua Pelaksana BIMWIN, fasilitator BIMWIN, peserta BIMWIN. Peneliti Juga melakukan observasi terhadap pelaksanaan BIMWIN tahun 2018 dan melakukan dokumentasi terhadap kegiatan BIMWIN. Penelitian ini dilakukan di kantor Bimas Islam Kabupaten Ponorogo, Kantor Urusan Agama Kecamatan Sukorejo dan Kantor Urusan Agama Kecamatan Slahung Kabupaten Ponorogo.

Analisis data mengacu pada model Miles dan Huberman dalam Sugiono (2016) dengan tahapan sebagai berikut (1) reduksi data yang merupakan kegiatan peneliti dalam merangkum dan memilih hal-hal yang pokok dengan memfokuskan pada hal-hal yang penting sehingga data yang telah direduksi memberikan gambaran yang lebih jelas dan memudahkan peneliti dalam melakukan pengumpulan data selanjutnya, (2) penyajian data dilakukan dengan teks naratif dimana hasil wawancara dinarasikan dalam bentuk tulisan untuk memudahkan peneliti memahami apa yang terjadi dan dapat dengan baik menggambarkan kesimpulan yang dijustifikasikan untuk menuju pada tahap analisis berikutnya, (3) penarikan kesimpulan merupakan langkah ketiga dalam aktivitas analisis data dalam penelitian ini. Kesimpulan yang dikemukakan oleh peneliti terus mengalami perubahan setelah ditemukan bukti-bukti yang kuat dan mendukung sehingga kesimpulan yang diambil merupakan kesimpulan yang telah didukung oleh bukti-bukti yang valid dan konsisten saat peneliti turun lapangan. Kesimpulan akhir yang diambil oleh peneliti merupakan kesimpulan yang kredibel.

\section{HASIL PENELITIAN DAN PEMBAHASAN}

Dalam upaya mencegah perceraian, Bimas Islam Kabupaten Ponorogo menyelenggarakan kegiatan Bimbingan Perkawinan (BIMWIN) bagi pasangan calon pengantin yang telah mendaftarkan diri di masing-masing Kantor Urusan Agama (KUA) kecamatan se-Kabupaten Ponorogo. Program ini telah berjalan sejak tahun 2017 dengan jumlah peserta 480 pasangan calon pengantin yang diselenggarakan di tiga tempat, yaitu bertempat di Aula Kantor Kementerian Agama Kabupaten Ponorogo, Aula KUA Kecamatan Sukorejo dan Aula KUA Kecamatan Slahung. Pelaksanan BIMWIN pada tahun 2017 dibagi menjadi 16 angkatan dengan jumlah peserta 60 orang pada masing-masing angkatan. Program ini merupakan bagian dari upaya pemerintah khususnya Bimas Islam Kabupaten Ponorogo dalam mewujudkan keluarga sakinah agar kasus tingginya angka perceraian di Kabupaten Ponorogo bisa di minimalisir. Muhtadin selaku ketua pelaksana Bimbingan Perkawinan Bimas Islam Kabupaten Ponorogo dalam wawancara dengan peneliti 
pada tanggal 24 Mei 2018.

"Secara sederhana yang kami sampaikan kepada masyarakat latar belakangnya adalah tinginya angka perceraian, sehingga salah satu cara untuk menekan angka perceraian agar menurun itu salah satunya program BIMWIN ini. Selain itu juga untuk mempersiapkan keluarga yang kuat kokoh sesuai dengan kebijakan pemerintah untuk menyiapkan keluarga yang kokoh termasuk nawa cita pak presiden. Ini setiap angkatan 2 hari, untuk tahun ini dapat dana untuk 28 angkatan masing-masing angkatan 25 pasang, kalau dihitung ada 1400 calon pengantin. Ada peningkatan dari tahun sebelumnya 480 pasang calon pengantin".

Untuk tahun 2018, pelaksanaan BIMWIN tetap di diselenggarakan di tiga lokasi yang telah ditetapkan oleh Bimas Islam dengan jumlah peserta 1.400 calon pengantin yang terbagi dalam 28 angkatan dengan jumlah masing-masing angkatan sebanyak 50 orang calon pengantin. Komponenkomponen komunikasi dalam pelaksanaan BIMWIN meliputi aspek fasilitator selaku komunikator yang menyampaikan materi BIMWIN, pemilihan media sebagai saluran dalam menyampaikan materi BIMWIN, pemetaan peserta BIMWIN serta efek yang diharapkan oleh Bimas Islam merupakan aspek penting yang diperhatikan dalam upaya mencapai keberhasilan program BIMWIN secara optimal. Adapun pelaksanaan BIMWIN sebagai strategi komunikasi Bimas Islam Kabupaten Ponorogo dalam mencegah perceraian mengacu pada rumusan strategi komunikasi sebagai berikut:

\section{Strategi Pemetaan Peserta BIMWIN}

Pemetaan peserta BIMWIN (komunikan) merupakan faktor penentu keber- hasilan dalam setiap aktivitas komunikasi yang dilakukan oleh Bimas Islam Kabupaten Ponorogo. Strategi pemetaan komunikan yang tepat dapat menjadi ukuran dari keberhasilan upaya Bimas Islam dalam mewujudkan keluarga sakinah. Wilbur Schramm dalam Riswandi mengatakan bahwa seorang perancang komunikasi yang baik tidak akan memulai dari "apa yang harus dikatakan", "saluran apa yang akan digunakan" atau "bagaimana cara mengatakannya", melainkan terlebih dahulu mempertanyakan "siapa yang akan menjadi komunikan sasaran" dari program kegiatan komunikasi tersebut. (Riswandi, 2009: 139).

Implikasi dari pernyataan Schramm adalah bahwa sebelum program BIMWIN dilaksanakan, pemetaan peserta sebagai komunikan dari kegiatan komunikasi yang dilakukan menjadi aspek penting yang harus diperhatikan agar materi-materi pesan yang disampaikan dapat diterima dengan baik oleh peserta BIMWIN, sehingga dalam konteks BIMWIN, strategi pemetaan komunikan dilakukan dengan pendekatan sosiologis dan pendekatan psikologis untuk mendapatkan data dan informasi mengenai karakteristik dari peserta BIMWIN.

Pemetaan komunikan dari aspek sosiologis dilakukan dengan memerhatikan jenis kelamin dan faktor umur peserta BIMWIN dimana komunikan dari kegiatan ini adalah calon pengantin laki-laki dan perempuan yang sudah cukup umur sesuai aturan yang telah ditetapkan dalam pasal 7 Ayat 1 Undang-undang Republik Indonesia Nomor 1 Tahun 1974 Tentang Perkawinan yang menyebutkan bahwa perkawinan hanya di izinkan bila pihak pria mencapai umur 19 tahun dan pihak wanita mencapai usia 16 tahun. 
Sementara dari aspek psikologis, program BIMWIN diarahkan untuk memenuhi kebutuhan dan harapan masing-masing pasangan calon pengantin dalam membangun rumah tangga. Mereka diberikan materi tentang tujuan utama dari sebuah perkawinan mulai persiapan sebelum menikah, membangun keluarga yang harmonis dan bagaimana cara menyelesaikan permasalahan keluarga ketika muncul konflik interpersonal antara suami dan istri agar tidak berujung pada terjadinya perceraian. Semua dilakukan sebagai upaya untuk dimenguatkan mereka dalam persiapan menikah sehingga setelah menikah nantinya mereka bisa hidup rukun dan harmonis dalam keluarga.

Kelemahan dari pemetaan peserta BIMWIN ini adalah belum memerhatikan aspek pendidikan peserta. Latar belakang pendidikan perserta juga menjadi faktor sangat menentukan keberhasilan penerimaan pesan yang disampaikan sehingga dalam pelaksanaan kegiatan BIMWIN ada beberapa peserta yang kurang memahami materi yang disampaikan fasilitor, akibat dari latar belakang pendidikannya yang masih rendah, sedangkan penyampaian materi pesan disampaikan dengan bahasa yang kurang praktis.

\section{Strategi Penyampaian Pesan}

Pesan komunikasi terdiri atas isi pesan dan lambang (simbol). Isi pesan bisa satu tetapi lambang pesan bisa bermacam-macam tergantung pada konteksnya. Setiap pesan komunikasi memiliki tujuan sebagaimana diharapkan oleh komunikator selaku pihak yang menyampaikan pesan. Implikasinya adalah komunikator harus menentukan teknik apa yang harus digunakan dalam menyampaikan pesan tersebut guna men- capai keberhasilan komunikasi. Pesan yang efektif adalah pesan yang sesuai dengan kebutuhan komunikan, apalagi efek yang diharapkan adalah perubahan sikap dan perilaku komunikan. Wilbur Schramm dalam karyanya "How Communication Woks" menyebutkan bahwa salah satu cara agar pesan yang disampaikan dapat diterima oleh komunikan, maka pesan harus dirancang dan disampaikan sedemikian rupa agar menarik perhatian komunikan serta pesan harus dapat membangkitkan kebutuhan pribadi komunikan. (Effendy, 2015: 33)

Dalam konteks BIMWIN, materi pesan disampaikan sesuai kebutuhan peserta yang dalam hal ini adalah calon pasangan pengantin yang sudah mendaftarkan diri di masing-masing KUA kecamatan seKabupaten Ponorogo. Adapun materi-materi yang disampaikan dalam kegiatan BIMWIN antara lain tentang membangun landasan keluarga sakinah, cara merencanakan perkawinan yang kokoh menuju keluarga sakinah, materi terkait dinamika perkawinan, menyiapkan kebutuhan keluarga, menyiapkan generasi berkualitas, materi tentang cara mengelola konflik serta materi tentang kesehatan keluarga termasuk didalamnya terkait kesehatan reproduksi.

Strategi penyampaian materi BIMWIN dilakukan dengan metode ceramah sebagai pengantar, kemudian dilanjutkan dengan diskusi kelompok yang di pandu fasilitator yang kompeten sesuai bidang keahliannya. Masing-masing kelompok diberikan waktu untuk membuat perencanaan perkawinan sesuai dengan materi yang disampaikan pada tiap-tiap sesi. Hal ini dilakukan dengan tujuan agar materi-materi yang disampaikan dapat diserap secara optimal oleh peserta BIMWIN dan menjadikan mereka tidak 
jenuh dalam mengikuti setiap sesi materi yang disampaikan dalam kegiatan BIMWIN yang diselenggarakan selama dua hari dengan estimasi waktu delapan jam perhari. Sebagaimana dikatakan oleh Nurul Hanifah selaku fasilitor BIMWIN dalam wawancara yang dilakukan oleh peneliti pada tanggal 06 Agustus 2018 di Aula Kantor Kementerian Agama Kabupaten Ponorogo.

"Ada materi tentang cara membangun keluarga yang kokoh, ada materi tentang mempersiapkan generasi berkualitas, ada materi mengelola konflik dan masih banyak materi lainnya karena ini berlangsung selama 2 hari. Intinya menyiapkan generasi calon pengantin ini bagaimana bisa mempersiapkan perkawinan itu dengan matang agar keluarga bisa langgeng, jadi keluarga yang sakinah. Materi kami terapkan dalam bentuk permainan-permainan agar mereka tidak jenuh, sehingga tanpa disadari materi akan diserap maksimal dengan permainan yang kami terapkan itu. Nanti kalau pas perkenalan itu ada permainan "angin bertiup", kemudian nanti ketika masuk materi mempersiapkan kelurga sakinah itu ada "sungai kehidupan". Angin bertiup itu ketika kita dalam rumah tangga itu ketika diterpa masalah, ada ujian, ada cobaan itu kita tetap kokoh berdiri tegak tidak goyah. Nah kalau sungai kehidupan itu bagaimana cita-cita kita membangun keluarga itu, jadi sungai kehidupan itu keluarga kita, anak kita kedepan itu seperti apa, 5 tahun kedepan itu bagaimana, apa saja target kita, jadi muaranya itu kemana begitu".

Hasil pengamatan yang dilakukan oleh peneliti dalam pelaksanaan BIMWIN di Aula Kantor Kementerian Agama Kabupaten Ponorogo pada Tanggal 06 Agustus 2018, menunjukkan bahwa peserta serius dan fokus dalam menerima materi yang disampaikan oleh fasilitator karena selain diskusi, strategi penyampaian pesan juga diterapkan dalam bentuk permainan-permainan yang membuat peserta tidak jenuh dan tanpa disadari materi yang disampaikan dapat terserap secara maksimal melalui permainan-permainan yang dijadikan sebagai strategi dalam penyampaian materi BIMWIN.

Metode ini merupakan pengembangan strategi penyampaian materi BIMWIN dari tahun sebelumnya dengan melihat hasil evaluasi dari pelaksanaan BIMWIN pada tahun 2017 yang hanya disampaikan melalui ceramah dan tanya jawab. Metode ceramah dinilai kurang efektif dalam proses penyampaian materi BIMWIN karena sebagian peserta tidak fokus dan jenuh dalam mengikuti kegiatan Bimbingan Perkawinan pra-nikah. Sebagaimana disampaikan oleh Hayat Prihono W. selaku Kepala Seksi Bimas Islam Kabupaten Ponorogo saat wawancara dengan peneliti pada tanggal 07 Mei 2018.

"Ini merupakan hasil evaluasi dari program BIMWIN tahun sebelumnya yang dirasa kurang tepat dan efektif. Sebelum materi program BIMWIN disampaikan juga dilakukan pretest terlebih dahulu dan dilakukan post test sesudahnya untuk mengukur keberhasilan program tersebut".

Dalam pelaksanan BIMWIN tahun 2018, strategi penyampaian pesan disesuaikan dengan kebutuhan peserta sehingga strategi penyampaian materi bukan hanya bersifat ceramah dan tanya jawab saja, tetapi lebih banyak dikemas dalam bentuk diskusi kelompok yang diselingi dengan permainanpermainan yang menarik dan dipandu oleh fasilitator-fasilitator yang kompeten dan menarik. Strategi penyampaian materi yang berfokus pada diskusi kelompok dari masing-masing calon pasangan pengatin, mampu mengeksplorasi pemikiran mereka 
terkait apa saja yang akan mereka lakukan ketika menjadi suami istri kelak. Melalui diskusi kelompok, masing-masing pasangan dapat mengeksplorasi pemikiran mereka tentang bagaimana perencanaan calon suami dan istri dalam membangun keluarga yang kokoh, menyiapkan kebutuhan keluarga baik kebutuhan fisik maupun kebutuhan non fisik, merencanakan generasi yang berkualitas dan bagaimana membangun komunikasi yang baik dalam keluarga agar sekecil apapun permasalahan yang muncul keluarga dapat di selesaikan dengan baik sehingga tidak berujung pada perceraian.

Melalui strategi penyampaian materi yang berfokus pada peserta, pelaksanaan BIMWIN 2018 menjadi lebih menarik karena masing-masing calon pengantin dapat merencanakan sendiri bagaimana cara membangun keluarga sakinah, program apa saja yang akan mereka lakukan untuk tahun pertama menikah sampai lima tahun kedepan. Mereka mengusulkan kemudian diskusikan bersama pasangannya hingga akhirnya disepakati bersama untuk dijadikan rujukan dalam menjalani kehidupan rumah tangga setelah mereka menikah nanti. Fasilitator memfasilitasi terhadap keberadaan dan kebutuhan peserta yang mengikuti program Bimbingan Perkawinan bagi calon pasangan pengantin yang berlangsung selama dua hari.

\section{Strategi Pemilihan Media}

Media yang digunakan dalam pelaksanan BIMWIN menggunakan LCD proyektor, papan tulis dan buku pedoman Fondasi Keluarga Sakinah. Pemilihan media-media tersebut dilakukan berdasarkan kondisi dan kebutuhan dalam penyampaian materi BIMWIN serta mengikuti Petunjuk Teknis (JUKNIS) yang telah ditetapkan oleh Ditjen
Bimbingan Masyarakat Islam Kemenag RI Tahun 2017.

Proyektor digunakan sebagai sarana dalam menyampaikan materi BIMWIN oleh fasilitator. Sedangkan papan tulis digunakan sebagai media bagi peserta dalam menulis perencanaan keluarga sakinah sesuai materi BIMWIN yang disampaikan pada tiaptiap sesi. Selain itu, peserta BIMWIN juga diberikan buku Fondasi Keluarga Sakinah sebagai pedoman dalam menjalani kehidupan rumah tangga. Buku ini diberikan kepada peserta sebagai sarana belajar agar bisa dipelajari kembali setelah mereka kembali kerumah masing-masing.

\section{Strategi Pemilihan Komunikator}

Komunikator adalah pihak yang mengirim pesan kepada komunikan. Peranan komunikator sangat penting dalam mengendalikan jalannya komunikasi.

Sebelum melakukan aktivitas komunikasi, komunikator harus memahami syarat apa saja yang harus terpenuhi dalam dirinya agar pesan yang disampaikan dapat diterima oleh komunikannya. Effendy dalam bukunya Ilmu Komunikasi; Teori Dan Praktek mengatakan bahwa terdapat dua faktor penting yang harus dimiliki oleh komunikator dalam melancarkan komunikasi, yaitu daya tarik komunikator dan kredibiltas komunukator. (Effendy, 2013: 39).

Komunikator yang dilibatkan dalam pelaksanaan BIMWIN adalah fasilitator yang telah mengikuti Training of Trainer (TOT) keluarga sakinah yang diselenggarakan oleh Kantor Wilayah Kementerian Agama Propinsi Jawa Timur dan fasilitator dari Dinas Kesehatan Kabupaten Ponorogo yang bertugas menyampaikan materi terkait 
kesehatan reproduksi bagi setiap pasangan calon pengantin yang mengikuti kegiatan BIMWIN. Hayat Prihono W. selaku Kasi Bimas Islam Kabupaten Ponorogo saat wanwancara dengan peneliti pada tanggal 20 April 2018 mengatakan:

"Tentunya fasilitator yang telah pengalaman terkait dengan materi perkawinan, ya utamanya kepala KUA senior yang kami libatkan, untuk yang Kasi disini yang ada kaitannya dengan Bimas sendiri dan Bimbingan Syariah. Diantara mereka sudah pernah menjadi narasumber ketika ada program Kursus Pengantin (SUSCATIN) sebelum program BIMWIN dilaksanakan. Mereka juga sudah ikut program TOT keluarga sakinah di Kanwil Kemenag Jatim, jadi fasilitator ini sudah pernah mengikuti program movitator dan konselor keluarga sakinah".

Kredibilitas komunikator dalam kegiatan BIMWIN menjadi aspek penting yang harus diperhatikan karena menyangkut kepercayaan komunikan kepada komunikator yang kredibel. Komunikator BIMWIN adalah fasilitator yang telah mengikuti pelatihan keluarga sakinah dan fasilitator dari Dinas Kesehatan yang kompeten dalam bidang kesehatan sehingga aktivitas komunikasi yang dilakukan dalam kegiatan BIMWIN menjadi optimal berdasarkan kepercayaan komunikan terhadap materi pesan yang disampaikan oleh fasilitator-fasilitator yang kredibel sesuai bidang keahlian yang dimiliki.

Daya tarik komunikator dalam pelaksanaan BIMWIN cukup menarik melihat kondisi saat peneliti melakukan observasi dalam kegiatan BIMWIN dimana beberapa fasilitator dalam menyampaikan materinya selalu disesuaikan dengan kondisi psikologis, menyangkut kebutuhan dan emosi komu- nikan. Ketika fasilitator menyampaikan materinya, konsentrasi peserta fokus kepada komunikator dan materi pesan yang disampaikan. Namun masih ada fasilitator yang kurang memahami kondisi psikologis komunikannya dalam menyampaikan materi. Fasilitator tersebut hanya berfokus pada metode ceramah, sehingga sebagian peserta menjadi jenuh dan tidak fokus terhadap materi yang disampaikan. Akibatnya terdapat beberapa peserta yang kurang memahami materi BIMWIN yang disampaikan oleh fasilitator yang kurang menarik karena merasa jenuh dan capek.

\section{KESIMPULAN}

Dalam rangka mewujudkan keluarga sakinah, Bimbingan Masyarakat Islam Kabupaten Ponorogo menyelenggarakan kegiatan Bimbingan Perkawinan bagi calon pasangan pengantin sebagai upaya dalam mencegah perceraian. Kegiatan ini bertujuan untuk meningkatkan kualitas kehidupan rumah tangga agar menjadi harmonis sehingga kasus tingginya perceraian di Kabupaten Ponorogo dapat diminimalisir. Pemetaan peserta dilakukan berdasarkan aspek sosiologis dan psikologis komunikan. Komunikan dari kegiatan BIMWIN adalah calon pasangan pengantin yang telah mendaftarkan diri di KUA kecamatan seKabupaten Ponorogo. Materi pesan yang disampaikan terkait landasan membangun keluarga sakinah dengan strategi penyampaian pesan melalui ceramah, tanya jawab dan diskusi kelompok. Media yang digunakan dalam penyampaian materi BIMWIN adalah LCD proyektor, papan tulis dan buku pedoman Fondasi Keluarga Sakinah. Strategi pemilihan komunikator dilakukan berdasarkan aspek kredibiltas 
dan daya tarik komunukator sehingga dalam kegiatan BIMWIN, komunikator yang menyampaikan materi adalah fasilitator Bimas Islam Kabupaten Ponorogo yang telah mengikuti TOT keluarga sakinah dan memiliki sertifikat sebagai konselor dan motivator keluarga sakinah serta fasilitator dari Dinas Kesehatan yang kompeten dalam bidang kesehatan keluarga.

Subtansi penelitian ini memberikan rekomendasi kepada Bimbingan Masyarakat Islam Kabupaten Ponorogo untuk terus melakukan bimbingan kepada masyarakat khususnya pasangan suami istri dalam membangun keluarga agar setiap keluarga dapat mewujudkan keluarga sakinah mawaddah warohmah sesuai dengan tujuan utama perkawinan sebagaiman telah disyari'atkan dalam ajaran Agama Islam. Untuk masyarakat, khusunya pasangan suami istri agar berupaya untuk membangun komunikasi yang baik dalam keluarga dengan selalu mengedepankan sikap jujur dan terbuka kepada masing-masing pasangan agar permasalah-permasalahan yang muncul dalam keluarga dapat diselesaikan dengan baik sehingga hubungan keluarga menjadi harmonis.

\section{DAFTAR PUSTAKA}

Al Qur'an dan Terjemahnya. 1418 H. Mujamma' Al Malik Fahd Li Thiba'at Al MushHaf Asy-Syarif Medinah Munawwarah

Cangara, H. Hafied. 2013. Perencanaan dan Strategi Komunikasi. Jakarta: Rajawali Pers.

Cangara, H. Hafied. 2016. Pengantar Ilmu Komunikasi. Jakarta: Raja Grafindo Persada.
Effendy, Onong Uchjana. 2015. Dinamika Komunikasi. Bandung: Remaja Rosdakarya

Effendy, Onong Uchjana. 2013. Ilmu Komunikasi; Teori dan Praktek. Bandung: Remaja Rosdakarya.

Kriyantono, Rachmat. 2014. Teknis Praktis Riset Komunikasi. Jakarta: Kencana Prenadamedia Group.

Mulyana, Dedy. 2016. Ilmu Komunikasi Suatu Pengantar. Bandung: Remaja Rosdakarya.

Moleong, Lexy J. 2014. Metodologi Penelitian Kualitatif. Bandung: Remaja Rosdakarya.

Riswandi. 2009. Ilmu Komunikasi. Yogyakarta: Graha Ilmu

Sugiyono. 2014. Metode Penelitian Kuantitatif, Kualitatif, dan $R$ \& D. Bandung: Alfabeta. 